\title{
The acquisition of English possessives by a bilingual child: Do input and usage frequency matter?
}

\author{
Elena BABATSOULI ${ }^{1}$ and Elena NICOLADIS ${ }^{2 *}$ \\ ${ }^{1}$ Institute of Monolingual and Bilingual Speech, Kalathas, Chania, Greece and ${ }^{2}$ Psychology, Faculty of \\ Science, University of Alberta, Edmonton, Canada \\ ${ }^{*}$ Corresponding author: Elena Nicoladis, Psychology, Faculty of Science, University of Alberta, 116 St. \\ and 85 Ave., Edmonton, AB, T6 G 2R3, Canada. E-mail: elenan@ualberta.ca
}

(Received 13 September 2016; revised 12 July 2017; accepted 3 September 2018; first published online 17 October 2018)

\begin{abstract}
Previous research in child language shows that many aspects of language acquisition are frequency-linked. This study tests whether input or usage frequency predicts the order of acquisition and accuracy of a bilingual Greek-English child's English possessives. The child was followed longitudinally from age $2 ; 6$ to $3 ; 11$. Order of acquisition was comparable to that of same-aged monolingual children. The child's usage frequency and order of acquisition were highly correlated with input frequency, while her accuracy was not. We argue that the child's already-acquired Greek possessives facilitated acquisition of English possessives, even though the child's English input and usage frequencies were lower than in monolingual English children.
\end{abstract}

Keywords: bilingual first language acquisition; input frequency; usage frequency

\section{Introduction}

Most previous studies on children's acquisition of possessive constructions have been framed in universal grammar and therefore on the innate mechanisms (García Mayo, Lázaro Ibarrola, \& Liceras, 2005; Radford, 1990; Radford \& Galasso, 1998; Rispoli, 1994, 1998, 2005). Nevertheless, input frequency likely influences acquisition of possessive words and morphemes (Ambridge, Kidd, Rowland, \& Theakston, 2015; Gülzow \& Gagarina, 2007). The link between frequency and children's acquisition is strong for words (Ambridge et al., 2015; Chan \& Nicoladis, 2010; Goodman, Dale, \& Li, 2008) and morphemes (Bybee, 1995; Kirjavainen, Theakston, \& Lieven, 2009). In this study, we test how input and usage frequency are related to a Greek-English bilingual child's acquisition of possessives in her weaker language (English). Input frequency refers to how frequently children hear linguistic units, and usage (or output) frequency refers to how frequently they themselves use those units.

Bilingual children generally hear and produce each of their languages less often than monolinguals (Nicoladis, 2016) and might therefore lag in their acquisition of 
frequency-related aspects relative to monolingual children, but still show the same process of acquisition (Nicoladis \& Marchak, 2011; Nicoladis \& Paradis, 2012). Indeed, several studies have shown that bilinguals lag behind monolinguals in vocabulary size (Morales, Calvo, \& Bialystok, 2013; Oller, Pearson, \& Cobo-Lewis, 2007; review in Bialystok, 2009), and that their vocabulary is related to their input frequency (David \& Li, 2008; Pearson, Fernández, Lewedeg, \& Oller, 1997). Similarly, studies have shown that bilingual children learn grammatical morphemes later than monolinguals but with similar patterns of acquisition (Jia, \& Fuse, 2007; Nicoladis \& Paradis, 2012; Nicoladis, Song, \& Marentette, 2012).

Some researchers assume that it is the input and/or usage frequency of a particular language that predicts bilingual acquisition (Nicoladis et al., 2012). However, another potential source of information for bilinguals is their other language (Bernardini \& Schlyter, 2004), as observed in terms of cross-linguistic influence with regard to word order and phonology, among other aspects of language (e.g., Serratrice, 2013). For example, bilingual children learning languages that differ in the order of nominal possessives (e.g., mommy's hat vs. le chapeau de maman 'the hat of mommy') show signs of cross-linguistic influence in both languages through reversal errors (Nicoladis, 2012). Cross-linguistic influence may bolster bilinguals' acquisition, particularly if the two languages are similar (Nicoladis, 2003). In the present study, we test whether the child's acquisition of possessives in English is related to her own usage frequency in her stronger language, Greek. If so, the results would challenge the assumption that it is the within-language frequency that predicts acquisition.

The present study focused on the bilingual child's attempts, accuracy, and order of acquisition of possessives. We tested how these variables related to the input frequency and the child's own usage of possessives. We also explored the possibility that her acquisition of possessives shows influence from her usage frequency in Greek.

\section{Acquisition of possessives}

Studies on monolingual acquisition of possessives focus on error types and order of acquisition. Though the word order of possessives is acquired early (e.g., 17 months in English: Tomasello, 1998, 2;6 in Greek: Marinis, 2003), common errors involve 's omission, use of nominative and accusative pronouns as pronominal possessives, intermixing of pronominal determiners with nominal pronouns, and erroneous $s$-inflection (e.g., me's) (for English: Bloom, 1970; Bowerman, 1973; Chiat, 1981, 1986; Radford, 1990; Radford \& Galasso, 1998; Tomasello, 1998, 2006; for German: Clahsen, Eisenbeiss, \& Penke, 1996; for Finnish, Luo, Samoan: Bowerman, 1973). Among the pronouns, my/mine, her, unstressed your, and its are among the least marked, while his and their involve frequent errors (Chiat, 1981).

As for order of acquisition of possessives, distinctions of gender, person, and number are among the most marked; my/mine and your/your are appropriately produced by children starting at 2;3, but their is delayed until 3;8 (Chiat, 1981, 1986; Radford \& Galasso, 1998; Rispoli, 1994). Rispoli (1994) showed that children between 2;0 and 3;0 used my far more frequently than his or her, which were more frequent than their. The age of first use and complete acquisition of 's varies across individual children (Christofidou, 1998; de Villiers \& de Villiers, 1973; Radford \& Gallaso, 1998; Stephany, 1997; Tomasello, 1998, 2006).

Most studies of bilinguals' acquisition of possessives focused on word order (Nicoladis, 2012; Van der Linden \& Blok-Boas, 2005). However, one study reported 
a similar order of acquisition for six- to eight-year-old sequential bilingual children to that of monolingual children for a range of grammatical markers, including possessive ' $s$ (Dulay \& Burt, 1974). These results support the argument that input frequency predicts order of acquisition (Ambridge et al., 2015; Bybee, 1995; Unsworth, 2016). However, we know of no previous studies systematically testing the link between input frequency and order of acquisition of possessives. Possessive 's is sometimes included as one datapoint in testing the relationship between input frequency and acquisition of various morphemes (Brown, 1973; de Villiers \& de Villiers, 1973). Not all studies, however, have shown that order of acquisition is related to input frequency (e.g., Brown, 1973; De Villiers \& De Villiers, 1973), suggesting that other variables, like complexity, also contribute to order of acquisition (Gathercole, 2016; see Ambridge et al., 2015).

\section{This study}

The present study tests the role of input and usage frequency in the acquisition of English possessive pronouns and 's by a Greek-English bilingual girl. She had acquired Greek possessives when data collection started at 2;6, earlier than the Greek monolingual children in Marinis (2003). The child, Maria Sofia, was born and raised in Greece by native Greek parents. The input she received in English started at age 1;0 and came only from her mother. The mother's and child's speech in English and the child's code-switching in Greek during their English interactions were digitally recorded with an Olympus WS11-311M recorder about 1 hour daily, 5 days a week from $2 ; 7$ to $3 ; 11$; data at $2 ; 6$ were collected for the child only and were recorded in diary notes. The recordings were made during routine mother/child interactions, e.g., playing, eating, book-reading, etc. A CLAN (MacWhinney, 2000) database of 511 files was created with orthographic and phonetic (IPA, 1999) transcriptions of the child's utterances in the recordings. Mother utterances were entered orthographically for the first five months.

The monthly utterances of mother's English and child's English and Greek are shown in Table 1 from 2;6 to 2;11. The correlation between the mother's and child's number of English utterances is high: 0.978 . There is a decrease of about $10 \%$ in the child's code-switching in Greek between 2;6 and 2;9 and between 2;10 and 2;11, showing the child's increasing ability to communicate in English.

We compare order/age of acquisition and error patterns to those of English monolinguals, also investigating likely cross-linguistic influence. Frequency correlations are investigated between the child's usage frequency (OUTPUT) in English and: (a) frequency in the INPUT; (b) accuracy/order of acquisition; (c) frequencies in monolingual adult-child interactions in ChildFreq (http://childfreq.sumsar.net); and (d) the child's usage frequency in Greek.

To determine errors, attempted usage was identified based on word order and meaning of the child's utterance in the conversational context. A major point is whether a child has acquired word-final $/ \mathrm{n} /$ and $/ \mathrm{s} /$, because adult-like production of possessives like mine, yours, ours depends on this; that is, if word-final $/ \mathrm{n} /$ and $/ \mathrm{s} /$ are not acquired, it cannot be determined whether the child uses the correct forms of possessives like mine, yours, ours, as they will be produced as my, your, our. The child acquired word-final /n/ and /s/ by $2 ; 7$.

Possessive constructions in Greek are shown in Table 2. The possessives system in both Greek and English consists of weak adnominal pronouns: $m u$ 'my', su-siNG 'your', tu 'his/its', tis 'her', mas 'our', sas-PLUR 'your', and tus 'their'; a periphrastic 
Table 1. Monthly Utterances of Mother's English and Child's English and Greek

\begin{tabular}{|c|c|c|c|}
\hline Age & Participant & English utterances & Greek utterances \\
\hline \multirow[t]{2}{*}{$2 ; 6$} & mother & - & - \\
\hline & child & 176 & 122 \\
\hline \multirow[t]{2}{*}{$2 ; 7$} & mother & 1,082 & - \\
\hline & child & 785 & 690 \\
\hline \multirow[t]{2}{*}{$2 ; 8$} & mother & 641 & - \\
\hline & child & 771 & 732 \\
\hline \multirow[t]{2}{*}{$2 ; 9$} & mother & 2,422 & - \\
\hline & child & 2,657 & 2,260 \\
\hline \multirow[t]{2}{*}{$2 ; 10$} & mother & 2,420 & - \\
\hline & child & 2,700 & 1,505 \\
\hline \multirow[t]{2}{*}{$2 ; 11$} & mother & 1,349 & - \\
\hline & child & 1,566 & 860 \\
\hline
\end{tabular}

Table 2. Greek Possessive Constructions

(I) Weak possessive pronouns (always in the genitive following a noun and its 'the')

\begin{tabular}{lllllll}
\hline \multicolumn{4}{c}{ Singular } & \multicolumn{2}{c}{ Plural } \\
\hline to 'poði mu & to 'poði su & to 'poði tu & to 'poði tis & to 'poði mas & to 'poði sas to' poði tus \\
\hline my foot & your foot & his/its foot & her foot & our foot & your foot & their foot \\
\hline
\end{tabular}

(II) Periphrastic possessive pronoun: declinable adjective ði'kos 'own' followed by (I)

\begin{tabular}{|c|c|c|}
\hline Singular/Plural & Singular & Plural \\
\hline 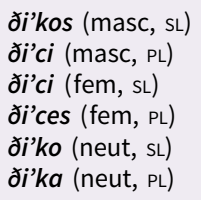 & $\begin{array}{l}\text { mu 'my own/mine' } \\
\text { su 'your own/yours' } \\
\text { tu 'his own/his' } \\
\text { tis 'her own/hers' }\end{array}$ & $\begin{array}{l}\text { mas 'our own/ours' } \\
\text { sas 'your own/yours' } \\
\text { tus 'their own/theirs' }\end{array}$ \\
\hline \multicolumn{3}{|c|}{ (III) The genitive of a declinable noun and of its obligatory determiner 'the' } \\
\hline & Singular & Plural \\
\hline \multicolumn{3}{|c|}{ Masculine } \\
\hline $\begin{array}{l}\text { tu 'jani } \\
\text { John's }\end{array}$ & $\begin{array}{l}\text { tu 'pinaka } \\
\text { of the writing board }\end{array}$ & $\begin{array}{l}\text { ton 'jániðon } \\
\text { the Johns' }\end{array}$ \\
\hline \multicolumn{3}{|c|}{ Feminine } \\
\hline $\begin{array}{l}\text { tis 'meris } \\
\text { Mary's }\end{array}$ & $\begin{array}{l}\text { tis 'yatas } \\
\text { of the cat }\end{array}$ & $\begin{array}{l}\text { ton psi'xon } \\
\text { of the souls }\end{array}$ \\
\hline \multicolumn{3}{|c|}{ Neuter } \\
\hline $\begin{array}{l}\text { tu spit'çú } \\
\text { of the house }\end{array}$ & & $\begin{array}{l}\text { ton spit'çón } \\
\text { of the houses }\end{array}$ \\
\hline
\end{tabular}


pronoun: ðikos $m u$, OWN MY 'my own'), and an inflectional genitive: Greek feminine noun ending in /a, i, u, o/ + genitive $s$ (e.g., 'meris-GEN 'Mary's'); English noun+'s (e.g., Mary's hat). Their differences lie in that: (i) only the POSSESSOR/POSSESSUM word order is permitted in English; this is the marked, emphatic option in Greek, which also permits POSSESSUM/POSSESSOR; (ii) determiner pronouns are prenominal in English (e.g., $\boldsymbol{m} \boldsymbol{y}$ hat) but postnominal in Greek (kapelo $\boldsymbol{m} \boldsymbol{u}$, HAT MY); and Iiii) Greek has no weak possessive pronouns with a nominal function, but English does (e.g., mine/ yours, etc.).

\section{Results and discussion}

\section{The child's mean length of utterance}

A comparison of mean length of utterance in words between the two languages at age 2;7 shows that Greek is the child's dominant language: there is a difference of more than one word (Bernardini \& Schlyter, 2004); 3.36 in Greek, higher than the range $(2.6,3.0)$ of the four Greek monolinguals in Marinis (2003), and 2.01 in English, seemingly lower than the mean of 2.91 and standard deviation of 0.58 of the 17 English monolinguals in Rice, Smolik, Perpich, Thompson, Rytting, and Blossom (2010), ranging from 2;6 to 2;11.

\section{Input and output}

We have computed and compared the mother's frequency of possessives with the child's on a monthly basis, 2;7-2;11. The results are shown in Table 3. Their did not appear in the child's speech and only appeared six times in the mother's speech. Theirs, hers, and its are the only possessives that did not appear at all.

There is a monthly increase in both participants' possessives, with the mother using more possessives $(13.4 \%$ at $2 ; 7: 22.9 \%$ at $2 ; 11)$ than the child $(4.3 \%$ at $2 ; 7: 14.3 \%$ at $2 ; 11)$; the percentages refer to the number of possessives per 100 utterances. The child-mother monthly variation in the number of possessives is characterized by a 0.893 correlation coefficient. My and your were the most frequent possessives in the child's and mother's speech, respectively (about 50\% of possessives usage), with 's the next most frequent, and ours and their/theirs being the least frequent possessive for both participants.

The monthly frequency correlation coefficient between the participants' different possessives is in the last column of Table 3. Because a mother uses your/yours and a child $m y / m i n e$ more often than vice versa, the correlation coefficient was computed by matching the mother's my/mine, your/yours respectively with the child's your/yours, my/mine; all other possessives were matched per type. The resulting correlation coefficient is 0.88 at $2 ; 7$, becoming higher $(\geqslant 0.93)$, at ages $2 ; 8-2 ; 11$ and showing a strong relationship between input and output usage frequency per possessive type. The child had already acquired the distinction between 1st and 2nd person in Greek (e.g., Budwig, 1996; Caët \& Morgenstern, 2015), a fact further supporting our analysis.

\section{Attempted possessives per language}

The role that the frequency of usage of possessives plays in their acquisition in this child's bilingualism is examined by computing the monthly frequency of possessives attempted in each language. This is shown in Table 4 from $2 ; 6-2 ; 11$. While the 
Table 3. Mother's Input (m) and Child's Output (c) In English Possessives from 2;7 to 2;11

\begin{tabular}{|c|c|c|c|c|c|c|c|c|c|c|c|c|c|}
\hline & $\mathrm{T}$ & my & mine & your & yours & our & ours & his & her & 's & sum & sum/utter. & modif. correl. \\
\hline age & & $\%$ & $\%$ & $\%$ & $\%$ & $\%$ & $\%$ & $\%$ & $\%$ & $\%$ & A & $\%$ & $r$ \\
\hline \multirow[t]{2}{*}{$2 ; 7$} & $\mathrm{~m}$ & 14.5 & 1.4 & 47.1 & 2.2 & 5.1 & 0.7 & 10.1 & 9.4 & 9.4 & 145 & 13.4 & 0.879 \\
\hline & c & 50.0 & 14.7 & 5.9 & 5.9 & 0.0 & 0.0 & 5.9 & 0.0 & 17.6 & 34 & 4.3 & \\
\hline \multirow[t]{2}{*}{$2 ; 8$} & $\mathrm{~m}$ & 24.0 & 0.0 & 52.1 & 4.0 & 1.2 & 0.0 & 3.0 & 2.6 & 13.1 & 75 & 11.7 & 0.977 \\
\hline & c & 55.2 & 5.2 & 17.2 & 5.2 & 0.0 & 3.4 & 0.0 & 0.0 & 13.8 & 58 & 7.5 & \\
\hline \multirow[t]{2}{*}{$2 ; 9$} & $\mathrm{~m}$ & 13.2 & 0.3 & 48.5 & 2.1 & 4.9 & 0.3 & 10.1 & 8.0 & 12.0 & 344 & 14.2 & 0.930 \\
\hline & c & 44.7 & 3.8 & 18.2 & 0.6 & 5.7 & 8.2 & 0.6 & 2.5 & 15.7 & 159 & 6.0 & \\
\hline \multirow[t]{2}{*}{$2 ; 10$} & $\mathrm{~m}$ & 10.9 & 3.2 & 54.0 & 3.2 & 6.1 & 0.5 & 8.8 & 4.4 & 8.0 & 443 & 18.3 & 0.975 \\
\hline & c & 56.9 & 1.2 & 18.5 & 1.2 & 7.1 & 1.8 & 1.8 & 1.2 & 10.2 & 325 & 12.1 & \\
\hline \multirow[t]{2}{*}{$2 ; 11$} & $\mathrm{~m}$ & 10.0 & 1.0 & 62.5 & 2.3 & 5.0 & 0.7 & 6.4 & 5.0 & 7.0 & 309 & 22.9 & 0.934 \\
\hline & C & 45.7 & 2.2 & 22.9 & 2.7 & 7.2 & 0.9 & 3.6 & 3.1 & 11.7 & 223 & 14.3 & \\
\hline
\end{tabular}

Note. Child's my/mine and your/yours are correlated with mother's your/yours and my/mine, respectively; all other possessives are correlated by surface form. 


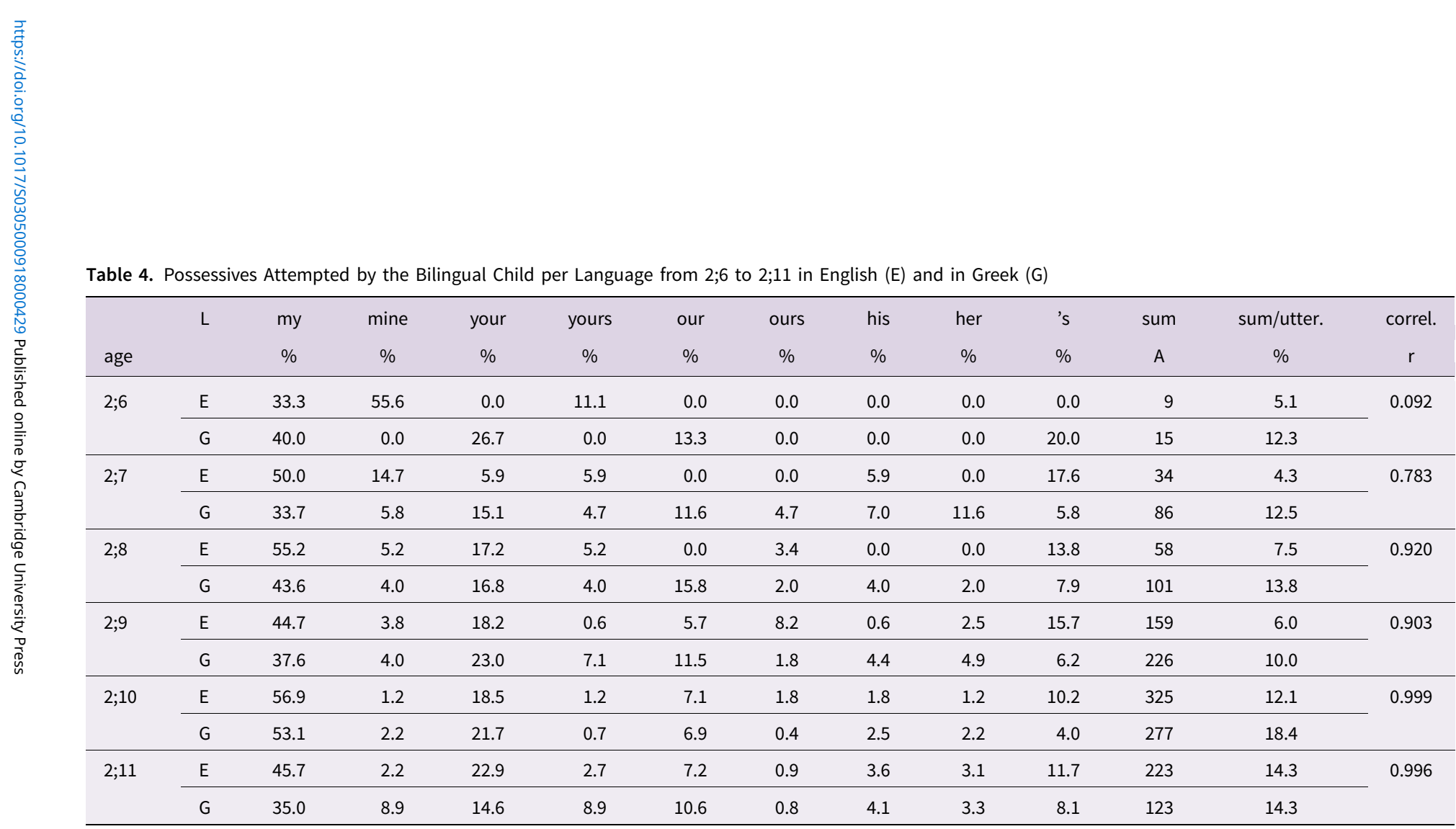


monthly increase in the child's attempted English possessives is high: $5.1 \%(2 ; 6)$ to $14.3 \%(2 ; 11)$, the monthly increase in Greek is insignificant: $12.3 \%(2 ; 6)$ to $14.3 \%$ $(2 ; 11)$, since they were already acquired at $2 ; 7$.

The frequency of attempts per possessive in each language is as follows: $m y$ is the most frequent (50\% of the times a possessive is attempted) in both languages, followed by your and 's, while ours is the least frequent for both participants. The monthly frequency correlation coefficient of the child's attempted possessives in both languages appears in the last column of Table 4: it is almost zero at 2;6 (inadequate data), much higher $(0.783)$ at $2 ; 7$, and perfectly matched $(0.995)$ at $2 ; 10-2 ; 11$. Thus, the child's attempted possessives are at a similar level in both languages in terms of distribution per possessive and their total number.

\section{Attempted possessives and accuracy in English}

The child's possessives in English are examined next in the entire database $(2 ; 6-3 ; 11)$, and monthly attempts are shown in Table 5. While my remains the most frequent possessive throughout, its frequency decreases by 3;2-3;4. The next most frequent your and the infrequent our increase at about this age. The number of possessive attempts per number of utterances increases until $2 ; 11$, reaching $14 \%$, and remaining at about this level thereafter. At about age three, the frequency of the dominant possessives ( $m y$, your, 's) decreases, owing to the increase in frequency of the lesser used possessives.

Table 6 shows the percentage of accurate (in terms of both form and function) realizations per possessive which, by about age three, is high in almost all possessives. As for accuracy and usage frequency, no significant correlation is found, meaning frequently used possessives are not necessarily the most accurate. A significant correlation emerged for my/mine, the least accurately produced longitudinally. $M y$ accuracy is positively/significantly correlated with the number of attempts $(r(18)$ $=.665, p<.01)$, the attempts per 100 utterances $(r(18)=.531, p=.044)$, and child age in months $(r(18)=.630, p=.047)$. Mine accuracy is positively correlated with number of attempts $(r(18)=.434, p=.02)$, and positively/significantly correlated with attempts per 100 utterances $(r(18)=.534, p=.045)$, and child age $(r(18)=.515, p=.048)$.

Last, the frequency data for my/mine/your/yours/our/ours/his/her were also obtained from monolingual English adult-child interactions in ChildFreq, computing the number of occurrences per million. The sum across age categories for all children in ChildFreq is used. Results, summarized in Table 7, show that there is good correspondence between the relative frequencies of words attempted by the child and of the same words in ChildFreq (see Table 7, 3rd column). In contrast, the correlations with accuracy are rarely significant and the two significant correlations are negative, meaning that the more frequently a particular word occurred in ChildFreq, the less accurate the child was. One reason for few significant correlations is the child's high accuracy.

\section{Order of acquisition, errors, and cross-linguistic influence}

The order of acquisition of possessives was determined based on the $90 \%$ level of accuracy, yielding the following results (Table 6): your/ours $(2 ; 8)$, 's $(2 ; 9)$, my/our $(2 ; 10)$, his/her $(2 ; 11)$, yours $(3 ; 0)$, their $(3 ; 1)$, mine $(3 ; 4-3 ; 9)$. Is this order of acquisition related to usage and/or input frequency? There is variability in accuracy 
Table 5. Possessives Attempted by the Bilingual Child in English from 2;6 to 3;11

\begin{tabular}{|c|c|c|c|c|c|c|c|c|c|c|c|}
\hline age & $\begin{array}{l}\text { my } \\
\%\end{array}$ & $\begin{array}{c}\text { mine } \\
\%\end{array}$ & $\begin{array}{c}\text { your } \\
\%\end{array}$ & $\begin{array}{c}\text { yours } \\
\%\end{array}$ & $\begin{array}{l}\text { our } \\
\%\end{array}$ & $\begin{array}{c}\text { ours } \\
\%\end{array}$ & $\begin{array}{l}\text { his } \\
\%\end{array}$ & $\begin{array}{l}\text { her } \\
\%\end{array}$ & $\begin{array}{l}\text { 's } \\
\%\end{array}$ & $\begin{array}{c}\text { sum } \\
\mathrm{A}\end{array}$ & $\begin{array}{c}\text { sum/utter. } \\
\%\end{array}$ \\
\hline $2 ; 6$ & 33.3 & 55.6 & 0 & 11.1 & 0 & 0 & 0 & 0 & 0 & 9 & 5.1 \\
\hline $2 ; 7$ & 50.0 & 14.7 & 5.9 & 5.9 & 0 & 0 & 5.9 & 0 & 17.6 & 34 & 4.3 \\
\hline $2 ; 8$ & 55.2 & 5.2 & 17.2 & 5.2 & 0 & 3.4 & 0 & 0 & 13.8 & 58 & 7.5 \\
\hline $2 ; 9$ & 44.7 & 3.8 & 18.2 & 0.6 & 5.7 & 8.2 & 0.6 & 2.5 & 15.7 & 159 & 6.0 \\
\hline $2 ; 10$ & 56.9 & 1.2 & 18.5 & 1.2 & 7.1 & 1.8 & 1.8 & 1.2 & 10.2 & 325 & 12.1 \\
\hline $2 ; 11$ & 45.7 & 2.2 & 22.9 & 2.7 & 7.2 & 0.9 & 3.6 & 3.1 & 11.7 & 223 & 14.3 \\
\hline 3;0 & 53.8 & 4.3 & 13.9 & 3.8 & 7.7 & 2.4 & 2.4 & 2.9 & 8.7 & 208 & 10.5 \\
\hline $3 ; 1$ & 45.8 & 2.6 & 13.9 & 1.4 & 8.4 & 2.6 & 9.6 & 5.8 & 9.9 & 345 & 11.5 \\
\hline $3 ; 2$ & 36.7 & 5.4 & 16.3 & 1.8 & 14.5 & 2.4 & 4.8 & 8.4 & 9.6 & 166 & 10.0 \\
\hline $3 ; 3$ & 39.5 & 3.2 & 26.8 & 2.5 & 8.9 & 0.0 & 8.9 & 5.1 & 5.1 & 157 & 9.9 \\
\hline $3 ; 4$ & 37.9 & 2.8 & 20.6 & 1.6 & 13.4 & 0.0 & 14.6 & 3.6 & 5.6 & 253 & 13.2 \\
\hline $3 ; 5$ & 38.2 & 4.6 & 20.5 & 2.3 & 11.2 & 0.0 & 9.7 & 7.3 & 6.2 & 259 & 16.9 \\
\hline $3 ; 6$ & 36.0 & 6.8 & 18.3 & 0.3 & 18.3 & 0.8 & 5.2 & 3.2 & 11.1 & 251 & 12.5 \\
\hline $3 ; 7$ & 42.9 & 5.3 & 14.8 & 2.6 & 9.0 & 2.1 & 16.4 & 1.1 & 5.8 & 189 & 10.9 \\
\hline $3 ; 8$ & 34.3 & 12.2 & 18.3 & 5.1 & 16.0 & 1.6 & 3.8 & 1.0 & 7.7 & 312 & 15.5 \\
\hline 3;9 & 38.5 & 3.6 & 18.0 & 3.0 & 15.0 & 3.9 & 5.3 & 4.2 & 8.6 & 361 & 16.5 \\
\hline $3 ; 10$ & 34.9 & 5.8 & 27.0 & 5.8 & 7.6 & 1.4 & 4.7 & 2.9 & 10.1 & 278 & 15.3 \\
\hline $3 ; 11$ & 36.3 & 5.7 & 23.2 & 1.9 & 18.8 & 0.3 & 3.2 & 1.3 & 9.2 & 314 & 19.3 \\
\hline
\end{tabular}


Table 6. Percentage (\%) of Attempted Possessives in English that Were Accurately Realized by Age

\begin{tabular}{|c|c|c|c|c|c|c|c|c|c|}
\hline age & my & mine & your & yours & our & ours & his & her & 's \\
\hline $2 ; 6$ & 66 & 100 & $\mathrm{n} / \mathrm{a}$ & 100 & $\mathrm{n} / \mathrm{a}$ & $\mathrm{n} / \mathrm{a}$ & $\mathrm{n} / \mathrm{a}$ & $\mathrm{n} / \mathrm{a}$ & $n / a$ \\
\hline $2 ; 7$ & 59 & 80 & 50 & 50 & $\mathrm{n} / \mathrm{a}$ & $\mathrm{n} / \mathrm{a}$ & 100 & $\mathrm{n} / \mathrm{a}$ & 100 \\
\hline $2 ; 8$ & 28 & 33 & 100 & 100 & $\mathrm{n} / \mathrm{a}$ & 100 & $\mathrm{n} / \mathrm{a}$ & $\mathrm{n} / \mathrm{a}$ & 75 \\
\hline $2 ; 9$ & 87 & 67 & 97 & 100 & 89 & 100 & 100 & 75 & 100 \\
\hline $2 ; 10$ & 99 & 75 & 98 & 50 & 100 & 100 & 83 & 100 & 100 \\
\hline $2 ; 11$ & 100 & 60 & 96 & 67 & 100 & 100 & 100 & 86 & 96 \\
\hline $3 ; 0$ & 99 & 56 & 97 & 100 & 100 & 100 & 100 & 100 & 94 \\
\hline $3 ; 1$ & 99 & 67 & 98 & 100 & 97 & 100 & 100 & 90 & 100 \\
\hline $3 ; 2$ & 100 & 67 & 100 & 100 & 100 & 100 & 100 & 100 & 100 \\
\hline $3 ; 3$ & 98 & 100 & 98 & 100 & 100 & $\mathrm{n} / \mathrm{a}$ & 100 & 100 & 75 \\
\hline $3 ; 4$ & 99 & 71 & 100 & 100 & 100 & $\mathrm{n} / \mathrm{a}$ & 100 & 100 & 100 \\
\hline $3 ; 5$ & 95 & 92 & 100 & 100 & 100 & $\mathrm{n} / \mathrm{a}$ & 100 & 100 & 94 \\
\hline $3 ; 6$ & 100 & 88 & 100 & 100 & 100 & 100 & 100 & 100 & 96 \\
\hline $3 ; 7$ & 100 & 80 & 100 & 100 & 100 & 100 & 100 & 100 & 100 \\
\hline 3;8 & 99 & 92 & 98 & 94 & 98 & 100 & 100 & 100 & 96 \\
\hline 3;9 & 100 & 85 & 98 & 100 & 100 & 100 & 100 & 93 & 97 \\
\hline $3 ; 10$ & 100 & 100 & 100 & 100 & 100 & 100 & 100 & 100 & 96 \\
\hline $3 ; 11$ & 100 & 100 & 100 & 100 & 100 & 100 & 100 & 100 & 100 \\
\hline
\end{tabular}

until 2;11, when most possessives were acquired. Between 2;7 and 2;11, the frequency of possessives in the child's input (exclusively by the mother), is, in descending order: your (706), my (161), 's (122), his (111), her (78), our (67), yours (34), mine (20), their (6), ours (6), while her usage frequency is in a different descending order: my (407), your (152), 's (98), our (48), his (17), her (15), mine (23), ours (23), yours (16).

In sum: (a) the least frequent in the input and the second-least frequent in the output, ours, is acquired first, alongside your, the most frequent in the input and second-most frequent in the output; (b) $m y$, the most frequent in the output and the second-most frequent in the input, is acquired third, together with our, considerably less frequent in both input and output (the fact that the input frequency of your is correlated with the usage frequency of $m y$ was mentioned earlier). Excluding $m y /$ ours, the higher the usage frequency, the earlier the age of acquisition.

The bilingual child's order of acquisition of possessives compares well with that of monolinguals with my, our/ours, your/yours, their/theirs (Chiat, 1981, 1986; Tomasello, 1998). She acquired his/her and 's at 90\% accuracy earlier than English monolinguals (Brown, 1973; Chiat, 1981, 1986; Radford \& Galasso, 1998; Tomasello, 1998) but showed delay with mine compared to monolinguals, despite her acquired coda /n/, which differentiates phonologically the my/mine contrast.

There is consistency in the child's error types found both in item-based contexts (i.e., specific pronouns like $m y$ ) and group contexts (e.g., determiner vs. nominal 
Table 7. Correlations between the Child's Possessives Attempts (and Accuracy) in English and ChildFreq Frequency

\begin{tabular}{|c|c|c|c|}
\hline age & utterances & $\begin{array}{l}\text { Correl between child's attempts } \\
\text { and ChildFreq frequency }\end{array}$ & $\begin{array}{c}\text { Correl between child's accuracy } \\
\text { and ChildFreq frequency }\end{array}$ \\
\hline $2 ; 6$ & 176 & 0.346 & $-0.997^{\star}$ \\
\hline $2 ; 7$ & 785 & $0.930^{\star \star}$ & -0.209 \\
\hline $2 ; 8$ & 771 & $0.957^{\star \star}$ & -0.623 \\
\hline $2 ; 9$ & 2,657 & $0.935^{\star \star}$ & 0.028 \\
\hline $2 ; 10$ & 2,700 & $0.966^{\star \star}$ & 0.315 \\
\hline $2 ; 11$ & 1,566 & $0.950^{\star \star}$ & 0.297 \\
\hline $3 ; 0$ & 1,998 & $0.968^{\star \star}$ & 0.134 \\
\hline $3 ; 1$ & 3,008 & $0.984^{\star \star}$ & 0.157 \\
\hline $3 ; 2$ & 1,671 & $0.929^{\star \star}$ & 0.152 \\
\hline $3 ; 3$ & 1,634 & $0.915^{\star \star}$ & $-0.778^{\star}$ \\
\hline $3 ; 4$ & 1,936 & $0.908^{\star \star}$ & 0.228 \\
\hline $3 ; 5$ & 1,529 & $0.951^{\star \star}$ & -0.365 \\
\hline $3 ; 6$ & 2,042 & $0.859^{\star \star}$ & 0.178 \\
\hline $3 ; 7$ & 1,748 & $0.949^{\star \star}$ & 0.168 \\
\hline $3 ; 8$ & 2,027 & $0.838^{\star \star}$ & 0.240 \\
\hline $3 ; 9$ & 2,173 & $0.913^{\star \star}$ & 0.163 \\
\hline $3 ; 10$ & 1,821 & $0.868^{\star \star}$ & 0.070 \\
\hline $3 ; 11$ & 1,618 & $0.819^{\star}$ & 0.070 \\
\hline
\end{tabular}

Notes. ${ }^{\star} p<.05 ;{ }^{* \star} p<.01$.

possessives), as in monolinguals (Chiat, 1981, 1986). Similarly to monolinguals, her errors involve gender intermixing (e.g., his/her), reversals of determiners and nominals (e.g., my/mine),'s omission / erroneous epenthesis, nominatives used for possessives (e.g., negligible $I /$ mine), nominal forms appearing before pronominal forms (e.g., yours/your), and repairs (Chiat, 1981, 1986; Radford \& Galasso, 1998; Tomasello, 1998). Some errors that are frequent among monolinguals were non-existent or negligible for this child: our for ours, errors with theirs, delayed acquisition of mine, your for my, etc. She never used accusatives for possessives.

With regard to the pattern of frequent reversal errors in bilinguals (Nicoladis, 2012), there is little such evidence here (i.e., two errors). Evidence of cross-linguistic influence is found in the pronominal use of the nominals: mine/yours/ours for my/your/our, respectively, which, although also attested in English monolinguals, is an overwhelmingly predominant error in this child, who may be transferring the Greek periphrastic possessive that has both a nominal and pronominal function.

\section{Concluding remarks}

This study investigated a Greek-English bilingual child's development of English possessives, with English being her weaker language in terms of exposure and use. 
Longitudinal data from $2 ; 6$ to $3 ; 11$ showed some evidence that her English possessives developed much like those of monolinguals. The child's usage of the different possessives was generally highly correlated with both frequency from ChildFreq and her input frequency. Also, the order of acquisition of possessives was similar to that of monolingual children (Chiat, 1981, 1986). For most possessives, our results are consistent with claims that order of acquisition and usage frequency are highly correlated (e.g., Ambridge et al., 2015; Bybee, 1995; Unsworth, 2016).

A surprising finding was that the child's accuracy in possessives was similar to that of same-aged English monolinguals (Chiat, 1981, 1986), despite limited exposure to English. The child also showed fewer kinds of errors in her production of possessives than previously reported for monolingual children. This result provides counter-evidence to some findings that bilinguals lag behind monolinguals (Jia \& Fuse, 2007; Nicoladis \& Paradis, 2012; Nicoladis et al., 2012).

We suggest that this child's English possessives were accurately acquired because she already knew possessives in Greek. In support of this suggestion, we found that the child's own usage of Greek possessives was highly correlated with her English possessives. Some studies have shown that bilingual children can benefit from cross-linguistic influence in acquisition (Bernardini \& Schlyter, 2004; Nicoladis, 2003), although in domains where the languages were structurally similar. While there are some surface similarities in the forms of Greek and English possessives, the differences outweigh the similarities. For that reason, this finding challenges versions of usage-based theories that assume frequency within a particular language relates to bilingual acquisition (e.g., Nicoladis et al., 2012). This finding supports the claim that bilingual children can use knowledge in one language to acquire the other (Bernardini \& Schlyter, 2004). In this case, the child knew that Greek marks possession. She did not have to learn that English marks possession, only how English marks possession. Future studies can test the generalizability of our interpretation with a larger sample of bilingual children and across other linguistic structures.

\section{References}

Ambridge, B., Kidd, E., Rowland, C. F., \& Theakston, A. L. (2015). The ubiquity of frequency effects in first language acquisition. Journal of Child Language, 42(2), 239-73.

Bernardini, P., \& Schlyter, S. (2004). Growing syntactic structure and code-mixing in the weaker language: the Ivy Hypothesis. Bilingualism: Language and Cognition, 7(1), 49-69.

Bialystok, E. (2009). Bilingualism: the good, the bad, and the indifferent. Bilingualism: Language and Cognition, 12, 3-11.

Bloom, L. (1970). Language development: form and function in emerging grammars. Cambridge, MA: MIT Press.

Bowerman, M. (1973). Early syntactic development. Cambridge University Press.

Brown, R. (1973). A first language: the early stages. Cambridge, MA: Harvard University Press.

Budwig, N. (1996). What influences children's patterning of forms and functions in early child language? In D. Slobin, J. Gerhardt, A. Kyratzis, \& D. Jiansheng (Eds), Social interaction, social context and language: essays in honour of Susan Ervin-Tripp (pp. 143-56). Mahwah, NJ: Lawrence Erlbaum.

Bybee, J. (1995). Regular morphology and the lexicon. Language and Cognitive Processes, 10, 425-55.

Caët, S., \& Morgenstern, A. (2015). First and second person pronouns in two mother-child dyads. In L. Gardelle \& S. Sorlin (Eds.), The pragmatics of personal pronouns (pp. 173-94). Amsterdam: John Benjamins.

Chan, W. H., \& Nicoladis, E. (2010). Predicting two Mandarin-English bilingual children's first 50 words: effects of frequency and relative exposure in the input. International Journal of Bilingualism, 14(2), 237-70. 
Chiat, S. (1981). Context-specificity and generalization in the acquisition of pronoun distinctions. Journal of Child Language, 8(1), 75-91.

Chiat, S. (1986). Children's pronouns. In U. Wiesemann \& J. Greenberg (Eds.), Pronominal systems (pp. 381-404). Tubingen: Gunter Narr.

Christofidou, A. (1998). Number or case first? Evidence from Modern Greek. In A. Aksu-Koç, E. Erguvanli Taylan, A. Sumru Özsoy, \& A. Küntay (Eds.), Perspectives on language acquisition: selected papers from the VIIth International Congress for the Study of Child Language (pp. 46-59), Istanbul: Bogazici University.

Clahsen, H., Eisenbeiss, S., \& Penke, M. (1996). Lexical learning in early syntactic development. In H. Clahsen (Ed.), Generative perspectives on language acquisition: empirical findings, theoretical considerations, crosslinguistic comparisons (pp. 129-159). Amsterdam: John Benjamins.

David, A., \& Li, W. (2008). Individual differences in the lexical development of French-English bilingual children. International Journal of Bilingual Education and Bilingualism, 11, 598-618.

De Villiers, J. G., \& De Villiers, P. A. (1973). A cross-sectional study of the acquisition of grammatical morphemes in child speech. Journal of Psycholinguistic Research, 2(3), 267-78.

Dulay, H. C., \& Burt, M. K. (1974). Natural sequences in child second language acquisition. Language Learning, 24, 37-53.

García Mayo, M. P., Lázaro Ibarrola, A., \& Liceras, J. M. (2005). Placeholders in the English interlanguage of bilingual (Basque/Spanish) children. Language Learning, 55, 445-89.

Gathercole, V. C. M. (2016). Factors moderating proficiency in bilingual speakers. In E. Nicoladis \& S. Montarnari (Eds.), Bilingualism across the lifespan (pp. 123-40). Washington, DC: De Gruyter Mouton.

Goodman, J. C., Dale, P. S., \& Li, P. (2008). Does frequency count? Parental input and the acquisition of vocabulary. Journal of Child Language, 35, 515-31.

Gülzow, I., \& Gagarina, N. (Eds.) (2007). Frequency effects in language acquisition: defining the limits of frequency as an explanatory concept (Vol. 32). Berlin: Walter de Gruyter.

IPA (1999). Handbook of the International Phonetic Association. Cambridge University Press.

Jia, G., \& Fuse, A. (2007). Acquisition of English grammatical morphology by native Mandarin-speaking children and adolescents: age-related differences. Journal of Speech, Language, and Hearing Research, 50 (5), 1280-99.

Kirjavainen, M., Theakston, A., \& Lieven, E. (2009). Can input explain children's me-for-I errors? Journal of Child Language, 36, 1091-114.

MacWhinney, B. (2000). The CHILDES project: tools for analyzing talk. Mahwah, NJ: Lawrence Erlbaum.

Marinis, T. (2003). The acquisition of the DP in Modern Greek (Vol. 31). Amsterdam: John Benjamins Publishing.

Morales, J., Calvo, A., \& Bialystok, E. (2013). Working memory development in monolingual and bilingual children. Journal of Experimental Child Psychology, 114, 187-202.

Nicoladis, E. (2003). Cross-linguistic transfer in deverbal compounds of preschool bilingual children. Bilingualism: Language and Cognition, 6(1), 17-31.

Nicoladis, E. (2012). Cross-linguistic influence in French-English bilingual children's possessive constructions. Bilingualism: Language and Cognition, 15, 320-8.

Nicoladis, E. (2016). Measuring language dominance in bilingual children: ramifications on predicting crosslinguistic influence. In C. Silva-Corvalán \& J. Treffers-Daller (Eds.), Operationalising and measuring language dominance (pp. 219-34). Cambridge University Press.

Nicoladis, E., \& Marchak, K. (2011). Le carte blanc or la carte blanche? Bilingual children's acquisition of French adjective agreement. Language Learning, 61, 734-58.

Nicoladis, E., \& Paradis, J. (2012). Acquiring regular and irregular past tense morphemes in English and French: evidence from bilingual children. Language Learning, 62, 170-97.

Nicoladis, E., Song, J., \& Marentette, P. (2012). Do young bilinguals acquire past tense morphology like monolinguals, only later? Evidence from French-English and Chinese-English bilinguals. Applied Psycholinguistics, 33, 457-79.

Oller, D. K., Pearson, B. Z., \& Cobo-Lewis, A. B. (2007). Profile effects in early bilingual language and literacy. Applied Psycholinguistics, 28, 191-230.

Pearson, B. Z., Fernández, V. L., Lewedeg, V., \& Oller, D. K. (1997). The relation of input factors to lexical learning by bilingual infants. Applied Psycholinguistics, 18, 41-58. 
Radford, A. (1990). The syntax of nominal arguments in early child English. Language Acquisition, 1(3), 195-223.

Radford, A., \& Galasso, J. (1998). Children's possessive structures: a case study. Essex Research Reports in Linguistics, 19, 37-45.

Rice, M. L., Smolik, F., Perpich, D., Thompson, T., Rytting, N., \& Blossom, M. (2010). Mean length of utterance levels in 6-month intervals for children 3 to 9 years with and without language impairments. Journal of Speech, Language, and Hearing Research, 53(2), 333-49.

Rispoli, M. (1994). Pronoun case overextensions and paradigm building. Journal of Child Language, 21, $157-72$.

Rispoli, M. (1998). Patterns of pronoun case error. Journal of Child Language, 25, 533-54.

Rispoli, M. (2005). When children reach beyond their grasp: why some children make pronoun case errors and others don't. Journal of Child Language, 32(1), 93-116.

Serratrice, L. (2013). Cross-linguistic influence in bilingual development: determinants and mechanisms. Linguistic Approaches to Bilingualism, 3(1), 3-25.

Stephany, U. (1997). The acquisition of Greek. In D. I. Slobin (Ed.), The crosslinguistic study of language acquisition (pp. 183-333). Hillsdale, NJ: Erlbaum.

Tomasello, M. (1998). One child's early talk about possession. In J. Newman (Ed.), The linguistics of giving (pp. 349-73). Amsterdam: John Benjamins.

Tomasello, M. (2006). Acquiring linguistic constructions. In D. Kuhn \& R. Siegler (Eds.), Cognition, perception, and language (pp. 255-98). Hoboken, NY: Wiley.

Unsworth, S. (2016). Quantity and quality of language input in bilingual language development. In E. Nicoladis \& S. Montarnari (Eds.), Bilingualism across the lifespan (pp. 103-21). Washington, DC: De Gruyter Mouton.

Van der Linden, E., \& Blok-Boas, A. (2005). Exploring possession in simultaneous bilingualism: Dutch/ French and Dutch/Italian. Eurosla Yearbook, 5, 103-35.

Cite this article: Babatsouli E, Nicoladis E (2019). The acquisition of English possessives by a bilingual child: Do input and usage frequency matter? Journal of Child Language 46, 170-183. https://doi.org/ $10.1017 /$ S0305000918000429 